Scientific Bulletin, № 2, 2021, pages 100-112

Kamil Fikiret Adishirinov, kamil.adisirinov@mail.ru

Sheki Regional Scientific Center, ANAS

DOI: doi.org/10.54414/mtss 7039

e-ISSN: $2789-4614$

\title{
DRAMA AND PROSE OF LUTFALI HASANOV
}

\begin{abstract}
In the article, there are being investigated drama and prose of Lutfali Hasanov who wrote and created works in Sheki literary atmosphere in 40-70thyears of XX century and led the literary council of 'Sabuhi" for a long time. The human ideas like the topicality of thoughts, patriotism, humanism, spiritu-al purity, honesty, uprightness, hate to war in the plays of playwright such as "Unsupported man", "In the land of brother", "Death to death", "Chief phy- sician", "The sun" and in the stories such as "Troubled man", "Deputy mana- ger, "The request", "Love for the son", "Zerrintac" and etc. are remarkable is- sues that the researcher wants to convey to the readers in the process of analyze. Deficiencies of society were openly criticized in the stories like "The request", "Troubled man", "Deputy manager" which include to the prose of writer. In the story of "Love for the son", there had been elucidated the role of child for the formation of sustainable family in the background of father's love for his son.
\end{abstract}

Keywords: playwright, prose, literary atmosphere, play, drama, type, story, writer, satirical prose, plot

\section{LÜTFӘLİ HəSЭNOVUN DRAMATURGIYASI VӘ NəSRI}

\section{XÜLASə}

Məqalədə XX əsrin 40-70-ci illərində Şəkidə yaşayı-yaratmış və uzun illər "Səbuhi" ədəbi məclisinə rəhbərlik etmiş Lütfəli Həsənovun nəsri və dramaturgiyası konkret istiqamətdən tədqiq edilmişdir. Dramaturqun "Dayaqsız adam", "Qardaş torpağında", "Ölümə ölüm", "Baş həkim", "Günəş" pyesləri- nin və "Narahat adam", "Direktor müavini", "Xahiş", "Oğul məhəbbəti", "Zərrintac" və başqa hekayələrinin əsas ideya xəttini təşkil edən vətənpərvərlik, insanpərvərlik, humanizm, mənəvi təmizlik doğruluq, həqiqətsevərlik, müharibəyə nifrət hissi kimi məsələlər təhlil prosesində oxucuya çatdırılır.

Yazıçının nəsr yaradıcılığına aid olan "Narahat adam", "Direktor müavini", "Xahiş" hekayələrində cəmiyyətdəki çatı̧̧mazlıqları açıq şəkildə tənqid edilmişdir. "Oğul məhəbbəti" hekayəsində yazıçı sağlam ailənin formalaşmasında uşaqların atanın öz oğluna məhəbbəti fonunda əks etdirmişdir.

Açar sözlər: dramaturq, nəsr, ədəbi mühit, dram əsəri, pyes, tip, hekayə, yazıçı, satirik nəsr, süjet.

\section{ДРАМАТУРГИЯ И ПРОЗА ЛЮТФАЛИ ГАСАНОВА}

\section{PЕЗЮМЕ}

В статье исследуется драматическое и прозаическое творчество Лютфали Гасанова, жившего и творившего в 40-70-е годы XX века в ли- тературной среде Шеки и долгие годы возглавившего литературный кру- жок (меджлис) «Сабухи». Идейная актуальность пьес драматурга «Человек без опоры», «На братской земле», «Смерть за смерть», «Главврач», «Гюнешь», рассказов «Беспокойной человек», «Заместитель директора», «Просьба», «Сыновняя любовь», «Зарринтадж» и другие, а также такие человеческое идеи, как патриотизм, человеколюбие, гуманизм, душевная чистота, честность, правдивость, ненависть к войне привлекают в ходе процесса анализа исследователя, которые он хотел довести до читателя. Недостатки в обществе в открытой форме критикуются в рассказах «Беспокойной человек», «Заместитель директора», «Просьба», входящие в прозу писателя. В рассказе «Сыновняя любовь» изображается роль детей в формировании здоровой семьи на фоне отцовской любви к своему дитя.

Ключевые слова: драматург, проза, литературная среда, драматическое произведение, пьеса, тип, рассказ, писатель, сатирическая проза, сюжет. 


\section{Giriş}

Məlumdur ki, milli ədəbiyyatın inkişafı region ədəbiyyatının tədqiqindən asılıdır. Buna görə də, milli ədəbiyyatın hər bir təmsilçisi ölkənin ayrı-ayrı regionlarını təmsil edir. Bu nöqteyi-nəzərdən XX əsrdə Azərbaycan ədəbiyyatında poeziyanın, nəsrin və dramaturgiyanın inkişafında qədim mədəniyyət mərkəzi olan Şəki mühüm yer tutur. Təqdim olunan məqalədə XX əsr Şəki ədəbi mühitinin istedadlı qələm sahiblərindən olmuş Lütfəli Həsənovun dramaturji və nəsr yaradıcılığı ilk dəfə olaraq tədqiq obyektinə çevrilib. Həkimyazıçı uzun İllər "Şəki fəhləsi" qəzetinin redaksiyası nəzdində fəaliyyət göstərmiş "Səbuhi" ədəbi məclisinə rəhbərlik etmişdir. Cəmiyyətdə gördüyü çatışmazlıqlara qarşı həmişə disident münasibət bildirən yazıçı sağlam cəmiyyət uğrunda mübarizəni həyatının əsas mənası hesab etmişdir. $O$, sağlam cəmiyyət uğrunda mübarizədə təkcə həkim kimi deyil, yazıçı kimi də sözün gücündən bacarıqla istifadə etmişdir.

$\mathrm{Bu}$ gün multikultural dəyərlərin qorunmas1 və təbliği sərhəddindən as1lı olmayaraq hər bir ölkənin əsas siyasət istiqamətidir. Buna görə, insanlıq o zaman sülh şəraitində yaşaya bilər ki, dinindən və irqindən asılı olmayaraq xalqlar arasında dostluq münasibətləri bərqərar olmuş olsun. Bu multikultural xüsusiyyətlərinə görə Lütfəli Həsənovun əsərləri ayrıca kitab kimi nəşr olunmasa da, dövri nəşr səhifələrindən oxucular tərəfindən məhəbbətlə qarşılanmışdır. Onun əsərlərinin qəhrəmanları müxtəlif xalqların nümayəndələri - ruslar, almanlar, azərbaycanlılar, gürcülər olmasına baxmayaraq onlar dost və qardaşdırlar. Bu dostluq telləri yazıçının dram əsərlərində daha diqqətçəkicidir.

\section{Lütfəli Həsənovun dramaturji yaradıcılığı}

XX əsr Şəki ədəbi mühitində Lütfəli Həsənov ən məhsuldar qələmə malik dramaturqdur. Onun şəxsi ev arxivində 7 dram əsəri qorunub saxlanılır. $\mathrm{Bu}$ əsərlərin bəziləri Şəki və Gəncə Dövlət Dram Teatrlarının səhnəsində tamaşaya qoyularaq böyük uğur və tamaşaçı rəğbəti qazanmışdır.

Dramaturqun ilk qələm təcrübəsi olan "İntiqam" pyesində hadisələr faşist düşərgələrinin birində cərəyan edir. Đsərdə dramaturq 200 nəfərdən artıq əsir qadının ağır həyatını - iki qadının: Xuraman və Elenanın şəxsində ümumiləşdirmişdir. Pyesdə Xuraman qorxmaz bir quz kimi təsvir edilir. O, faşist zabitləri Krauze və Şulsu qulağında gizlətdiyi zəhərlə zəhərləyib öldürür.

"Dayaqsız adam" pyesinin mövzusu kolxoz həyatından, kənd məişətindən götürülmüşdür. Osər realist müşahidələr əsasında yazılmışdır. Osərin baş mənfi qəhrəmanı kolxoz sədri Mürşüdovdur. Özbaşınalıq, mənəm-mənəmlik onun həyat idealıdır. Mürşüdov köhnəlik qalığı kimi yeniliyi sevmir, kolxozun aqronomu, gənc, ali təhsilli mütəxəssis Bəxtiyarın kolxozun inkişafı və kolxozçuların rifahı naminə olan təkliflərini qulaqardına vurur.

Mürşüdovun diqqətsizliyi ucbatından kolxozçular əmək intizamını pozur. Sədrin qızı Məlahət atasının bu özbaşınalığına dözmür. Onun bu məsələ- 
lərlə bağlı atasının müavini Bəxtiyara dediyi: "Qorxursunuz! Bu sədrə hörmət yox, pərəstiş və yaltaqlıqdır" [1, səh.148; 21] kimi sözləri Mürşüdovun iç üzünü açan vasitədir.

Osərdə Mürşüdov eyni zamanda qorxaq bir adam kimi təsvir edilir. O, gənc Bəxtiyarı öz yerinə göz dikməkdə günahlandırır, gecələr yuxusu ərşə çəkilir. Müəllif onu ayrı-ayrı surətlərlə rastlaşdıranda müxtəlif psixoloji vəziyyətlərdə verir. O, kolxozçular qarşısında özünün dediyi kimi “pələngə” bənzəyirsə, İstehsalat İdarəsinin yeni partiya rəhbəri Vəkilovun qarşısında müti qula çevrilir. Mürşüdov Xəlilovun qəbulunda gənc aqronom Bəxtiyarın ünvanına böhtanlar yağdıraraq onu gözdən salmağa çalışır.

Mürşüdov insafən kolxoz sədri olsa da, kolxozun əmlakını dağıtmayıb. Onun öz sözləri ilə desək "atadan qalan evdən başqa heç nəyi yoxdur" [1, səh. $149 ; 21]$. Lakin o, dayaqsızdır. Osl dayağı olacaq bir qüvvəni - xalqın etimadını itirib. Osərin sonunda oxucu onun maskalanmış siması ilə tanış olur. Vaxtilə kənddə tikilməsinin əleyhinə olduğu xəstəxana xəstələnərkən onun köməyinə çatır. O, artıq anlayır ki, köhnə iş üsulu ilə işləməyin vaxtı keçmişdir. Buna görə də, sədrlikdən çıxarılmaq yox, özü uzaqlaşmaq istəyir. Đsərin sonunda Mürşüdovun q1zı, yeni fikirli aqronom Məlahət kolxoz sədri seçilir.

Osərin sonunda Mürşüdovun müəllifə dediyi sözlər böyük maraq doğurur: "Siz yazıçısınız, uydurmalısınız. Get, bala, get! Məni sakit burax! İllər keçər, qayıdarsan, mənim yaratdığım kolxozun nə hala düşdüyünü görərsən" [1, səh.149; 21]. Maraqlı müraciətdir. Osər 1964-cü ildə qələmə alınıb. Görəsən, bir tipin dilindən söylənmiş fikirlə Lütfəli Həsənov haradan bilirdi ki, zaman keçəcək, onun təsvir etdiyi çürük özüllü kolxoz sistemi dağılaraq yalnız tarix səhifələrində qalacaq.

Osərin müsbət surətləri sırasında kolxozun ilk partiya təşkilat katibi Səlim, gənc aqronomlar Bəxtiyar və Məlahət mühüm yer tutur. Səlim əsərdə epizodik planda verilmişdir. $\mathrm{O}$, daim Mürşüdovun haqsız danlaqları ilə üzləşir. Mürşüdov heç bir işdə onunla hesablaşmır.

Osərin müsbət qəhrəmanı olan Bəxtiyar Mürşüdovun qızı Məlahət xan1mı sevdiyi üçün iki yol ayrıcında qalmışdır. $O$, Mürşüdovun səhvlərini üzünə deməkdə acizlik edir, onun nifrətini qazanmaq istəmir.

Dramaturq pyesdə mühiti üçün xarakterik olan ara həkimi kimi bəlalı bir məsələyə də öz münasibətini bildirmişdir. Đsərdə bu ümumiləşdirmə ara arvad1 Məsmənin üzərində aparılmışdır. Məsmə qarı yaramaz hərəkətlərini həyata keçirməkdə Mürşüdova arxalanır. Onun Mürşüdova isnadən: "Səni min yaşayasan. Bircə gün bu kənddə olmasan aləm bir-birinə qarışar. Gedək, a kişi, arxamızda Mürşüdov kimi dağ durur" [1, səh.150; 21], sözləri oxucuda və tamaşaçıda ona qarşı nifrət hissi yaradır.

Müəllifin Məsmə kimi surətlərə gülüşü epizodik surət olan Đlyəsənin dili ilə tam açıqlanır. Dramaturq Məsmə kimi çöpçüləri tənqid edərək yazır: "Məsmə xala, sənə bir sualım var. Dünyada üç milyard adam var. Hələ de- 
yirlər daha çoxdur. Niyə bu çöp ancaq bizim uşaqların boğazında qalır?” [1, səh. 150; 21], sözləri istehzalı tənqid xarakteri daşıır.

Lütfəli Həsənovun dram yaradıcılığının ən dəyərli əsərlərindən biri "Baş həkim" [1;7] pyesidir. Osərin baş müsbət qəhrəmanı baş həkim Muradovdur. Hadisələr rayon xəstəxanalarından birində cərəyan edir. Mənzər adlı ayaqları iflic vəziyyətində olan xəstəyə münasibətlə surətlərin daxili aləmi açılır. Müəllif ülvi həkimlik sənətinin sirlərini, həkimlərin Hippokrat andına hansı səviyyədə sadiq olub - olmadığını əsərdə mərkəzi surətlər olan Muradov, Təranə, Orşad, Rüstəm, Şakir və başqaları vasitəsi ilə açıb göstərir. Pyesdə mənfi və müsbət surətlər qütbü əsərin ilk səhifələrindən oxucunun diqqətini cəlb edir. Osərin müsbət qütbündə qocaman həkim, bütün xəstələrin sevimlisi $\mathrm{Mu-}$ radov və gənc həkim Təranə dayanır. Təranə gənc olmasina baxmayaraq istedadlı həkimdir. Tibb elminin yeni nailiyyətlorini gözəl bilir. $O$, istedadlılara dayaq, savadsızlara düşmən olan professor Nəcəfzadənin qızıdır. Təranə xəstə Mənzərin sağalmaz dərdinə böyük ümidlə baxır, onu yaşamağa, həyata həvəsləndirir. Bu işdə Təranənin dayağ1 və məsləhətçisi xəstəxananın baş həkimi Muradovdur. Lakin dünya paxillardan və pislərdən hali deyil. Təranənin zəngin biliyi, həkimlik qabiliyyəti korafəhim, savadsız, aspiranturadan və işlədiyi kafedradan qovulan, baş dolandırmaq üçün rayona qaçan Şakiri narahat edir. O, nəinki savadsız, həmçinin acıdil, ləyaqətsiz və əxlaqsız bir insandır. Osərdə müəllif bu tipin iç üzünü açmaq üçün müxtəlif situasiyalardan istifadə edir. Şakirin Mənzər haqqında dediyi: "Mən əminəm ki, Mənzər ömürlük şikəstdir. Belə bir xəstəni şöbədə saxlamaq, iynələmək, bədənini dəlik-deşik etmək, nəhayət, şöbənin ölüm faizini süni olaraq artırmaq" [1, səh.151;7] kimi sözləri onun nəinki bir həkim kimi, həmçinin mənən yoxsul bir şəxs kimi də oxucunun və tamaşaçının gözündən salır. Təranənin gənc tədqiqatçı kimi qazandığı uğurlar Şakiri narahat edir. Paxıllıq hissi onu rahat buraxmır. O, səlahiyyətlərindən istifadə edərək gənc həkimə böhtan atır. Xəstəxanada ölmüş gənc oğlanı Təranənin öldürdüyünü söyləməklə onu hədələyir. Bu hadisələr Təranəni təngə gətirir. $\mathrm{O}$, bu barədə Muradova bildirib xəstəxanadan işdən çıxmaq istəyir. Muradov ona təskinlik verərək, mübariz və təmkinli olmağa çağırır.

Şakir Təranəyə nəinki bir əməkdaş kimi paxıllıq edir, həmçinin onun şəxsi həyatına da qarışır. O, Təranəni sevən həkim Rüstəmə Təranə haqqında iftiralı, böhtan xarakterli sözlər deyir. Şakir həmçinin xəstəxananın normativlərinə əməl etmir. Xəstələr üçün ayrılmış dərman preparatlarının onlara verilməsini məhdudlaşdırır. O, Təranənin xəstələrə iynəni qaydasında təyin etdiyini bildikdə özünə sığmır, şöbə müdiri səlahiyyətlərindən istifadə edib onu təhqir edir. Şakir öz çirkin əməlləri ilə təkcə kollektivdə deyil, ailəsində də sevilmir. O, ailəsinə xəyanət edərək, həyat yoldaşı Mehribandan ayrılmaq qərarına gəlir. Osərin birinci şəkli bu cür başa çatır.

İkinci şəkil xəstəxanada növbədə olan Rüstəmlə Təranənin söhbəti ilə başlanır. Baş həkim Muradov Təranəni ayıq-sayıq olmağa çağırır. Şəklin so- 
nunda Şakirin iyrənc hərəkəti tamaşaçının nəzərinə çatdırılır. O, həyasızcasına Təranəyə eşq elan edir.

Osərin ikinci hissəsi Muradovla Şakirin mükaliməsi ilə başlanır. Şakir hərəkətlərinə görə yoldaşlıq məhkəməsinə verilmişdir. O, artıq vicdanı oyanmış haldadır.

Dramaturq əsərdə namuslu, saf, təmiz məhəbbəti hər şeydən üstün tutan surətlər də yaratmışlar ki, Rüstəm və Keybala bu qəbildəndir. Keybala Mənzəri sevir. Onun sevgisi ülvi sevgidir. Oxucu bunu onun Mənzər haqqında dediyi aşağıdakı sözlərdən də görür: "Bilmirəm. Mənzər bəxtimə çıxan ulduzdur. Kor da, keçəl də olsa qəbulumdur" [1, səh. 151;7]. Osərin ikinci hissəsi nikbin bir sonluqla, Mənzərin ayaq açıb gəzməsi ilə bitir.

Osərin üçüncü hissəsində dramaturq Şakiri artıq mənən təmizlənmiş bir insan kimi tamaşaçılara təqdim edir. Xəstəxananın laboratoriyasında güclü yanğın baş verir. Şakir həyatını təhlükə altında qoyaraq laboratoriyanın qiymətli avadanlıqlarını qurtara bilir. Nəticədə özü ağır yanır. Dramaturq onu xəstəxanada təsvir edir. Atası evinə getmiş həyat yoldaşı Mehriban da artıq onun yanındadir.

Osəri diqqətlə izləyən tamaşaçı və oxucu görür ki, pyesdə hadisələr mənfidən müsbətə doğru inkişaf edir. Hadisələri bu istiqamətə aparan isə baş həkim Muradovun təmkinliyi, müdrikliyidir. Lakin çox təəssüfləndirici haldır ki, bu müsbət ideal dünyadan köçür. Dramaturq onu elə-belə öldürmür. Artıq Muradovun bütün arzuları həyata keçmişdir. Osərin əvvəlində bütün mənfi keyfiyyətləri ilə yadda qalan Şakir, artıq əsərin sonunda dəyişərək tamamilə mənən kamil bir insan səviyyəsinə yüksəlmişdir. Çox maraqlıdır ki, Muradovun ölümü Şakirin qucağında təsvir edilir.

Gözəl ideyallar ifadə edən bu əsərin nəşr olunmamasına baxmayaraq, əsər 1966-c1 ildə Kirovabadda (indiki Gəncə) tamaşaya qoyulmuşdu və səhnəyə çıxarılmasına bu gün də ehtiyac duyulur. Osər dil və quruluş etibarı ilə də bitkin təsir bağışlayır. Müəllif əsərdə atalar sözləri və deyimlərimizdən, obrazların dialoqunda şeir parçalarından da məharətlə istifadə etmişdir.

Lütfəli Həsənovun dramaturji yaradıcılığında "O qayıdacaqmı?" adlı 4 pərdəli, 11 şəkilli pyesi də mühüm yer tutur. Bu pyes də mövzu etibarilə həkimlərin həyat və fəaliyyətinə həsr edilmişdir. Bu əsər "Baş həkim" pyesinin birinci variantı təsiri bağışlayır. Çünki əsərdəki personajlar eyni vəzifəli və eyni adlı insanlardır. Osərdə diqqəti cəlb edən yeni surətlər Pərvin və Camaldır.

Dramaturqun Böyük Vətən müharibəsi mövzusunda yazdiğ 1 "Ölümə, ölüm” [1, səh. 24], əsəri yaradıcılı̆̆ının ən müvəffəqiyyətli əsərlərindən hesab edilə bilər. Osər "Qardaş torpağında" adı altında yazılmış, sonra isə müəllif tərəfindən adı dəyişdirilmişdir. Pyes Azərbaycan Yazıçılar İttifaqının orqanı olan "Azərbaycan” jurnalının (İyun) 6-cı nömrəsində nəşr edilmişdir.

"Qardaş torpağında"[1;3] pyesi Azərbaycan və rus xalqları arasındakı dostluğa, müharibədə faşizmə qarşı aparılan birgə mübarizəyə həsr edilmişdir. 
Kamran, İftixar, Poladov kimi qəhrəman azərbaycanlılarla yanaşı digər xalqların nümayəndələrini təmsil edən Neqov Alesandr Serqeyeviç, Volkov, Adolf Vilfoviç, Stepan Rudnik, Gordtruda, Karl, Xausman, Zümmer, Oksana, Kneller, Fangelski kimi surətlər də vardır.

Lütfəli Həsənovun dram əsərləri sırasında ən maraqlı nümunələrdən biri onun "Günəş" [1, səh. 23] pyesidir. Bu əsər müəllifinə böyük uğur gətirmiş, Kirovabad (indiki Gəncə) Dövlət Dram Teatrında müvəffəqiyyətlə tamaşaya qoyulmuşdur. Tamaşanın uğuru və aktyor heyəti ilə bağlı xalq şairimiz Bəxtiyar Vahabzadə aşağıdakı qeydləri yazmışdır: "Osərin baş qəhrəmanı Günəşdir. Bu məsuliyyətli rolu respublikamızın xalq artisti Rəmziyyə Veysəlova oynayır. Günəş - R.Veysəlova qəhrəman bir qızın obrazıdır. Onun ürəyi, canı, vətəninə, xalqına olan böyük və sarsılmaz məhəbbətdir. R.Veysəlova ifa etdiyi rolun mahiyyətini dərindən anlamış, onu qavramağ bacarmışdır.

"Günəş" əsərində ikinci yadda qalacaq obraz Azər obrazıdır. Bu maraqlı rolu istedadlı artist Kərim Sultanov oynayır. Azər gestapo idarəsi rəisi Kraustinin "yavəridir". O, burada Azər yox, Şneyder adlanır. Bacarıqlı artist bu rolu olduqca məharətlə oynamaqla bərabər, sovet kəşfiyyatçısının qüdrətini tamaşaçılar qarşısında elə böyük ustalıqla canlandırır ki, onlar Azəri - K.Sultanovu dəfələrlə alqışlayırlar.

Tamaşada M.Cəfərovun ifa etdiyi Salmanov obrazı da çox maraqlı obrazdır. Salmanov ilk səhnələrdə məhəbbəti naminə sadəlövhlük edir. Onun sovet həkiminə yaraşmayan hərəkətləri tamaşaçının nifrətinə səbəb olur. Lakin sonralar Salmanov tamamilə başqa bir insan olur. Süjetin sonrakı inkişafında Salmanovun fədakarcasına ölümü, tamaşaçıları olduqca təəssüfləndirir.

Tamaşadakı qüvvətli obrazlardan biri də casus Qənbərovdur. Bu mürəkkəb rolu respublikamızın əməkdar artisti S.Həsənzadə özünəməxsus bir ustalıq və məhəbbətlə yaradır.

Respublikamızın xalq artisti M.Burcalıyev "Günəş" dramasında gestapo idarəsi rəisi Kaustini oynayır. Lakin demək lazımdır ki, o, gülüş xatirinə oynadığı obrazı həddindən ziyadə yüngülləşdirir ki, bu da tamaşaçıların narazılığ ${ }^{-}$ na səbəb olur.

Respublikanın xalq artisti Ә.Yusifzadə Rubanov, əməkdar artist S.Mustafayeva Bənövşə, artist Ә.Rzayev- Tərlan rollarında yaxşı çıxış edirlər.

Tamaşanın relissoru respublikanın əməkdar incəsənət xadimi Hüseyn Sultanov əsərin ideyasını yaxşı anlamış, gənc müəllifə qayğıkeşliklə yanaşmış, onunla uzun müddət işləmiş və nəticədə isə maraqlı bir tamaşa meydana çıxmışdır.

Bəstəkar Ş.Axundovanın tamaşaya yazdığ 1 musiqi əsərin gedişinə uyğundur və hadisələri yaxşı tamamlayır" [1, səh.154; 25].

Osərin nöqsanlarını qeyd edərkən Bəxtiyar Vahabzadə yazır: "Tərlan Günəşin oğludur. Onu öldürürlər. Lakin övladının ölümündən sonra ana onu heç xatırlamır. Proloq səhnəsində Qənbərovun Şahini necə inandırıb, onunla 
sərhəddi keçməsi tamaşaçılara çatmır.

Osərin sonunda oğulla ata (Qəmbərovla Şahin) qarşılaşmır ki, bu da əsərin müvəffəqiyyətini azaldır. Tamaşada operasiya səhnəsi zəif verilmişdir. Gestapoçuların səhnəyə gəlməsi az əsaslandırılmışdır. Osərdə Rıbakov obrazı tamamlanmamışdır'"[1, səh.154; 25].

Osərin q1sa məzmunu belədir: Hər tərəfdən top səsləri, pulemyot şaqq1ltıları eşidilir. Sovet döyüşçülərinin ağır hücumu zamanı bölmə komandiri Şahin Aslanov ağır yaralanır. Qaranlıqda bir kölgə ona yaxınlaşır. Şahin onu vurmaq istərkən o səslənir ki, "mən düşmən deyiləm, sənə kömək etmək istəyirəm” [1, səh. 154]. Ovvəl Şahin inanmır. Sonra yad adam Şahini inandırır və onu arxasına alıb arxaya doğru sürünür. Məlum olur ki, həmin kölgə həkimin sənədlərini əldə etmiş casus Qənbərovdur. Qənbərov yara aldığ1 üçün sovet xəstəxanasına düşür. Xəstəxananın həkimi Şahinin anası Günəşdir. Şahin sağaldıqdan sonra yeni təyinat alıb başqa istiqamətə gedir. Qənbərov isə xəstəxanada qalıb işləməyə başlayır və az bir zamanda böyük hörmət qazanır. O, Bənövşə, Tərlan və Salmanov kimi təcrübəsiz insanlarla yaxınlaşıb onları ələ alır və onların dolaşıq məhəbbət məcərasından istifadə edərək cinayətə sürükləyir. Onun toruna birinci həkim Salmanov düşür. Lakin Salmanov tezliklə Qənbərovun hiyləsini başa düşüb onunla dalaşır. Tərlan köməyə gəlir. Qənbərov onu öldürür. Qənbərov tərəfindən Tərlanın öldürülməsi xəbəri hərbi xəstəxanaya çatır. Sonra hadisələr sürətlə dəyişir və gərginləşir. Xəstəxana düşmən arxasında qalır və partizanlarla əlbir fəaliyyət göstərir. Qənbərov fitnəkar əməllərini həyata keçirməkdə davam edir. O, Günəşi gestapoçuların əlinə verir. Günəş həbsdə olarkən Qənbərov onun yanına gələrək yalvarır, keçmiş günləri xatırladır. Tamaşaçı əsərin bu yerində Qənbərovun keçmişi ilə tanış olur. Məlum olur ki, Qənbərov Azərbaycanın qudurğan bəy nəslindən olan Şahmar bəydir. O, vaxtılə Günəşi götürüb qaçaraq özünə arvad etmişdir. Onun axtardığ 1 və faşistlərə vermək istədiyi alaya isə doğma oğlu Şahin komandirlik edir. Günəş hadisələrin əsil mahiyyətini gestapoya düşdükdən sonra bilir. O, vətənpərvər bir Azərbaycan qızı, incə qəlbli və duyğulu bir anadar. Qəlbində faşist işğalçılarına nifrətlə alışıb - yanan Günəş müharibənin ilk günlərindən cəbhəyə gəlmişdir. O, gestapoda hər cür əzab-əziyyətə dözür, düşmənə satılmır və: - Siz mənə iki nömrəli cəza yox, yüz iki nömrəli cəzanı versəniz də, heç bir sirr öyrənə bilməyəcəksiniz, - deyir.

Gestapo rəisi Kraustinin partizan alayını və Şahini ələ keçirmək ümidləri boşa ç1xır. O, Günəşə dəhşətli işgəncələr verir, ancaq Günəş dözərək susur. Kraustin əsərdə əsil faşist xislətli bir zabit kimi canlandırılmışdır. Onun müharibədə iştirakı yalnız şəxsi arzularını həyata keçirmək, hərbi rütbəsini artırmaqdır. O, ülvi insanlıq hisslərinə tamamilə yad bir surətdir. Dramda Kraustinin yanında Şneyder surəti tamaşaçıların diqqətini cəlb edir. Bu cəsur kəşfiyyatçı partizan Azərdir. Şneyder əsərdə məşhur alman Hindenburqun bacısı oğludur. Azər bacarıqlı bir kəşfiyyatçı kimi Salmanovu faşist əsirliyindən qa- 
çırır. O, Qənbərovu düşmənlərə partizan casusu kimi qələmə verib həbs etdirir. Məhz onun cəsurluğu sayəsində məşhur faşist zabitləri olan Kraustin və Rozental əsir alınır... Osər bu cür maraqlı hadisələr fonunda davam edir və tamaşıçalarda vətənpərvərlik ruhu aşılayır.

Odibin dramaturji fonunda "Qara eynəkli adam" [1, səh.22], “Okeanın o tayında" [1] kimi üzərində geniş tədqiqat aparılması tələb olunan əsərləri də daxildir. Yazıçının "Qardaş torpağında" əsəri istisna olmaqla (qeyd etdik ki, bu əsər "Azərbaycan jurnalının 1956, 6 iyun sayında nəşr edilmişdir), yerdə qalan dram əsərləri əlyazması şəklində evində saxlanılır və inanırıq ki, gələcəkdə bu əsərlər Azərbaycan dramaturgiyasının müvəffəqiyyətli əsərləri sırasinda öz yerini tutacaqdır.

\section{Lütfəli Həsənovun hekayə yaradıcılığı}

XX əsrdə bütövlükdə Azərbaycan ədəbiyyatında olduğu kimi, ayr1-ayrı bölgələrdə də hekayə janrı yazıçıların qələmində özünü göstərməkdə idi. Bədii nəsrin bu kiçik forması Şəki ədəbi mühitinin digər ədəbi nümayəndələri kimi Lütfəli Həsənovun yaradıcılığında da özünə geniş yer almışdı. Həkim-yazıçının gözü mühitin hər üzünü görür, əyri-əskiklərini seçirdi. Müəllifin nəsrinin inkişafında "Şəki fəhləsi" qəzeti və onun redaktoru, qorxmaz və həqiqətsevər jurnalist Məhyəddin Abbasovun böyük rolu olmuşdu. Odibin cəmiyyətin müxtəlif təbəqələrindən seçdiyi tiplərin müsbət və mənfi baxımdan əks etdirdiyi hekayələri ən çox "Şəki fəhləsi" qəzetinin səhifələrində oxuculara çatdırılmışdı. Onun hekayə yaradıcılığını mövzu-mündəricə etibarilə iki qismə ayırmaq olar: 1. Satirik məzmunlu hekayələr; 2. Məişət hekayələri.

Yazıçının "Narahat adam" [9], "Sual" [1], "İstək" [1], "Yeni müdir" [1], "Qiymətlər və sifətlər" [9], "Göz ağrısı" [8], "Canfəşanlıq" [11], "Xahiş" [10], "Müdir müavini” [4], "Onu kim öldürdü?" [2] və s. kimi hekayələri satirik məzmunludur.

"Narahat adam"[9] hekayəsində yazıçı rəis Oləmdarov surətilə özündən razı, hikkəli bir məmur surəti yaratmışdır. Zəhmətkeşlərin rifahına laqeyd münasibət bəsləyən bu tip Şəki Mənzil İstismar İdarəsinə rəhbərlik edir. Oləmdarov qəbuluna gələn adamları laqeyd qarşılayır, onların vacib həll olunası məsələlərini aylarla uzadır. Hekayədə müəllif kiçik süjet xətti ilə Oləmdarovun yaltaq simasını aşağıdakı kimi oxucusuna təqdim edir. Oləmdarov qəbuluna gələn adamın kimliyini bilməyərək onu qəbuluna buraxmır, gələn "narahat adam"1n nazir olduğunu bildikdə isə müəllifin təsviri kimi: "Oləmdarov çevrilib stol arxasına keçdi və oradan onu görmək istəyən narahat adamın üstünə atılmaq istəyirdi ki, birdən nə oldusa qulaqları aşağ 1 sallanmış dovşana döndü. Gələn nazir idi. Oləmdarov onun qaşısında müti qula döndü.’'[9] Müəllif zəmanəsi üçün səciyyəvi olan idarə müdirlərinin özbaşınalığını və yaltaqlığını çox qabarıq şəkildə oxucuların nəzərinə çatdırmışdır.

Odibin "Müdir müavini”" [1;4] hekayəsində də eyni bu sujet oxşarlığ 
diqqəti cəlb edir. O, Balammədov surəti ilə 50-60-cı illərdəki ticarət və ticarətdəkilərin harın həyatını realistcəsinə müasir oxucuya çatdırır. Müəllif Baləmmədovu bir müavin kimi öz "səmimiliyi”, "mehribanlı̆̆g”," "sədaqəti” və "qayğıkeşliyi" ilə başqalarından qabarıq verir. Baləmmədov bu xüsusiyyətlərinə görə irəli çəkilir. Rayon İcraiyyə Komitəsinin rəhbərliyi onu ticarət müəssisəsinə müdir qoymaq təklifini irəli sürür. Baləmmədov müdir təyin edilir. Lakin Baləmmədov müdir tikəsini uda bilmir. Yumşaq kreslo, xidmətində olan "Pobeda", arvadının istəkləri onun beynini dumanlandırır. O, səlahiyyətlərini aşaraq özünə yeni təyin edilmiş müavini düzgünlüyünə görə işdən çıxarır. Bu işdən çıxarılma Baləmmədovun faciəsini dərinləşdirir. İdarəyə gəlmiş yoxlama komissiyası Baləmmədovu işdən azad edir: "Təmtəraqlı kabinet də, arvadının çox sevdiyi "Pobeda" da, müdir kabinetinin əzəmətli açarları da Baləmmədovun əlindən çıxır" [1, səh. 157; 4].

Yazıçının satirik nəsrində "Xahiş" [1;10] hekayəsi də mühüm yer tutur. Hekayədə tənqid hədəfi idarə rəisi Qolayzadədir. Müəllif bu tipin portretini rəngarəng boyalarla yaradaraq yazır: "Səftəralı rəis kabinetinin meşinli qap1sını qorxa-qorxa aralayıb içəri boylananda toxsun sifətli, peysəri yoğun, mərtəbə buxaxlı Qolayzadə özünü elə dartıb oturmuşdu ki, uzaqdan baxanlar onun boğazında sümük qalmış hacıleylək quşuna bənzədə bilərdi” [1, səh.157;10]. Bu təsvir Qolayzadənin kimliyini, şəxsiyyətini müəyyənləşdirmək üçün oxucuya kifayət edir. Səftəralı kimi miskin adamlar ona qol-qanad verib, istismarına, harın həyat sürməsinə şərait yaradırlar. Lütfəli Həsənov Qolayzadənin Səftəralı ilə mükaliməsini yazıçı istedadı ilə verir. Bu mükalimənin bir tərəfində özündənrazı amir məmur, digər tərəfində isə qorxaq, miskin, özünün və balalarının yemədiyi təamları dəbdəbəli süfrəyə düzüb, Qolayzadə kimi adamlara yedirmək üçün onu evinə qonaq dəvət etməyə yalvaran yaltaq bir tip durur. Lütfəli Həsənovun satirası bitib-tükənməzdir. Onun satira işığında yaşadığı cəmiyyətin bütün təbəqələri özünəməxsusluğu ilə əks edilib.

Odibin əsərləri sırasında fədakar insanların, zəhmətkeş adamların həyatını, məişətini əks etdirən hekayələri də çoxluq təşkil edir. Müəllif insanın öz əməyi ilə ucalmasın1, əməyin həqiqətən şöhrət-şan olması ideyasını "Ata və oğul" [1; səh.16] hekayəsində Sərdar kişi və oğlu Muxtarın şəxsində canlandırmışd1. Muxtar Sərdar kişinin oğludur. O, traktorçuluqda yüksək iş göstəriciləri əldə etdiyinə görə Sosialist Oməyi Qəhrəmanı adına layiq görülür.

Müəllf "Zərrintac" [1; səh.18] hekayəsində Cənubi Azərbaycan zəhmətkeşlərinin ağır güzəranını Zərrintac adlı bir qızın acınacaqlı həyatı fonunda təsvir etmişdir.

"Oğul məhəbbəti" hekayəsində Lütfəli Həsənov iqtisadçı Nadir surəti ilə ailə səadətini kənar təsirlərlə itirmək təhlükəsi ilə üzləşən insanların taleyini qələmə almışdır. Nadir Səadət adlı bir qızla qarşılıqlı sevgi əsasında ailə həyatı qurub evlənmişdir. $\mathrm{O}$, xoşbəxt ailə həyatı yaşayır. Rəşad adlı oğlu da dünyaya gəlmişdir. Lakin Nadirin Kirovabada (Gəncəyə) işləməyə getməsi ilə 
vəziyyət dəyişir. O, işlədiyi müəssisədə Sənubər adlı iqtisadçı bir qızla tanış olur. Onun ailəsinin varlığı təhlükə altındadır. Nadir iki yol ayrıcındadır. O, ya Sənubərin təsiri altına düşüb, ailəsini atmalı, ya da işini atıb Şəkiyə-ailəsinin yanına qayıtmalıdır. Oğul məhəbbəti üstün gəlir. Nadir iş yerini dəyişərək ailəsinin yanına qayıdır.

Yazıçının "Saxta məhəbbət" [13], "Etiraf" [14]," Axırı nə oldu" [15], "Xasiyyətnamə" [17], "Nişan üzüyü qayıtdı" [19], "Baş tutmadı" [11], "Yolda söhbət" [11], "İki dost" [5], “ Ah o gecə" [6] və s. kimi onlarla hekayələrində cəmiyyətin müxtəlif tərəfləri əks etdirilmişdir.

Nəticə: Mövzunun tədqiqi aktual səciyyə daşııır. Lütfəli Həsənovun dram və nəsr əsərləri regional aspektdən cəmiyyətdə mənəvi tərbiyə işlərinin həyata keçirilməsində və məişətinin öyrənilməsində mühüm əhəmiyyət kəsb edir. Həkimlik fəaliyyəti ilə bağlı həyatı dərindən müşahidə edən yazıçı dram əsərlərində yaratdığ 1 mənəviyyatca kamil insan surətləri ilə müqəddəs Hippokrat andına sədaqətini nümayiş etdirmişdir. Cəmiyyətin inkişafının əsas qarantı olan mənəvi tərbiyənin vəzifələri insanın taleyinin əsas götürülməsi, rüşvətxorluğa qarşı mübarizə, insan maraqlarına hörmət və ehtiram Lütfəli Həsənovun təhlili etdiyimiz əsərlərinin əsas ideya letmotividir.

Məqalə regional aspektdən ən yeni dövr Azərbaycan ədəbiyyatının, xüsusilə onun XX əsrdə əhəmiyyətli qolu olan Şəkidə ədəbi mühitin öyrənilməsində mühüm əhəmiyyət kəsb edəcəkdir.

\section{Odəbiyyat:}

1. Adışirinov K.F. XX əsr Şəki ədəbi-mədəni mühiti: 1900-2000-ci illər. I Kitab: Monoqrafiya. Bak1: Elm və təhsil, 2015, 488 s.

2. Həsənov L.Ә. Onu kim öldürdü? Novella, "Lenin bayrağı”, qəz., Şəki, 1964, 19 fevral

3. Həsənov L Ә. Qardaş torpağında // Azərbaycan, 1956, № 6 (6iyul)

4. Həsənov L. Ә. Müdir müavini: hekayə. "Nuxa fəhləsi", qəz., Nuxa, 1959, 18- 21 yanvar

5. Həsənov L. Ә. İki dost: hekayə. "Nuxa fəhləsi”, qəz., Nuxa, 1958, 30 may, 1 iyun

6. Həsənov L. Ә. Ah o gecə: hekayə. "Nuxa fəhləsi”, qəz., Nuxa, 1958, $24-$ 26-29 oktyabr

7. Həsənov L. Ә. Baş həkim: pyes. "Nuxa fəhləsi”, qəz., Nuxa, 1966, 16 yanvar

8. Həsənov L. Ә. "Göz ağrısı”, “Təzə müdir və təzə bina”.// Kirpi, Bak1, 1961, № 17, səh 6

9. Həsənov L. Ә. Miniatürlər: "İstək”, “Qiymətlər və sifətlər", "Narahat adam". "Şəki fəhləsi", qəz., Şəki, 1973, 24 noyabr

10. Həsənov L. Ә. Xahiş. Hekayə. "Şəki fəhləsi”, qəz., Şəki, 1971, 27 
fevral

11. Həsənov L. Ә. "Canfəşanlıq", "Baş tutmadı", "Yolda söhbət": hekayələr. "Şəki fəhləsi”, qəz. Şəki, 1968,3 fevral

12. Həsənov L. Ә. Qəribə idi: hekayə. "Şəki fəhləsi”, qəz., Şəki, 1970, 2224-26 dekabr

13. Həsənov L. Ә. Saxta məhəbbət: hekayə. "Nuxa fəhləsi”, qəz., Nuxa, 1956, 4-8-11-13 aprel

14. Həsənov L. Ә. Etiraf: hekayə. "Şəki fəhləsi”, qəz., Şəki, 1971, 10 mart

15.Həsənov L. Ә. Axırı nə oldu: hekayə. "Nuxa fəhləsi”, qəz., Nuxa, 1960, 5 fevral

16. Həsənov L. Ә. Ata və oğul: hekayə. "Nuxa fəhləsi”, qəz., Nuxa, 1961, 12-14 aprel

17. Həsənov L. Ә. Xasiyyətnamə: hekayə. "Şəki fəhləsi”, qəz., Şəki, 1971, 13 mart

18. Həsənov L. Ә. Zərintac: hekayə. "Nuxa fəhləsi”, qəz., Nuxa, 1961, 9 12- 14-16-19 iyul

19. Həsənov L. Ә. Nişan üzüyü qayıtdı: hekayə. "Nuxa fəhləsi”, qəz., Nuxa, 1959, 21 avqust

20. Həsənov L.Ө. İntiqam: pyes. (əlyazması, şəxsi arxivi)

21. Həsənov L.Ә. Dayaqsız adam: Pyes. (əlyazması, şəxsi arxivi)

22. Həsənov L.Ә. Qara eynəkli adam: Pyes (əlyazması, şəxsi arxivi)

23. Həsənov L.Ә. Günəş: pyes (əlyazması, şəxsi arxivi)

24. Həsənov L.Ө. Ölümə-ölüm: pyes (əlyazması, şəxsi arxivi)

25. Vahabzadə B. "Günəş" pyesi haqqında mülahizələrim (əlyazması: Lütfəli Həsənovun şəxsi arxivi) 